\title{
Usporedba karakteristika sorata vinove loze Babica i Tribidrag
}

\section{Sažetak}

Vinogorje Kaštela-Trogir je područje uzgoja mnogih autohtonih sorti vinove loze. Od crnog sortimenta najzastupljenija je sorta Babica. Nakon što je DNK analizom utvrđena genetska istovjetnost kalifornijskog Zinfandela, te talijanskog Primitiva s Tribidragom započinje njegova revitalizacija. Iz komercijalnih razloga površine pod Tribidragom se povećavaju, a Babice i ostalih sorti opadaju. Dok se zadnjih godina pojavljuju neke nove okolnosti koje otežavaju uzgoj Tribidraga, Babica zaslužuje biti predmetom vinogradarskog interesa, tim više što sve mogućnosti njenog enološkog potencijala nisu u potpunosti iskorištene.

Ključne riječi: Babica, Tribidrag, Vinogorje Kaštela-Trogir, povijesne činjenice, usporedba

\section{Uvod}

Vinogradarsko-vinarska aktivnost na području današnjeg Kaštelansko-trogirskog vinogorja datira od davnina (Piljac, 2005). Unatoč devastaciji prirodnih proizvodnih potencijala i snažnoj deagrarizaciji, uzgoj vinove loze na tom području je ipak opstao do danas. lako je stanje zastupljenosti pojedinih sorti bitno drugačije negoli je to bilo prije šezdesetak, a pogotovo prije sto i više godina, glavnina autohtonih kultivara toga područja je ostala očuvana (Vuletin, 1998). Među crnim kultivarima kao što su Plavac mali, Glavinuša, Ljutun, Rogoznička, Ninčuša i Dobričić, ističe se sorta Babica (Slika 1) kao jedna od najzastupljenijih u sortimentu priobalnog područja od Splita do Trogira (Karoglan Kontić, 2006). lako je Babica, sve donedavno, bila dominantna u sortimentu navedenog vinogorja, širem krugu poznavatelja vinove loze, pa čak i stručnjacima s ostalih vinorodnih područja Hrvatske, ostala je praktički nepoznata, te je iz tog razloga kao i zbog njenih svojstava i zastupljenosti bila predmet našeg interesa.

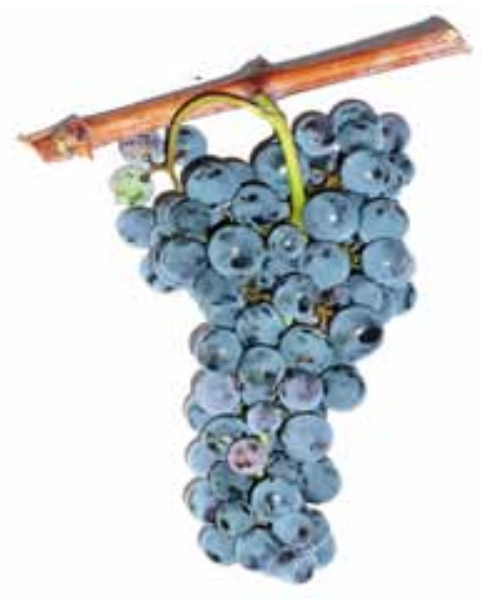

U posljednjem se desetljeću puno napravilo na reafirmaciji tradicionalnog sortimenta, a neke su sorte doslovce spašene od nestanka (Pijac, 2005).

Slika 1. Grozd Babice

Figure 1. Babica grape cluster

Izvor/Source: foto Ž. Skračić

Živko Skračić, dipl.ing, Srednja škola Braća Radić, Put poljoprivrednika bb, HR-21217 Kaštel Štafilić, Hrvatska (zivko.skracic@st.htnet.hr) prof.dr.sc. Mara Banović, Prehrambeno-biotehnološki fakultet Sveučilišta u Zagrebu, Pierottijeva 6, HR-10000 Zagreb, Hrvatska 


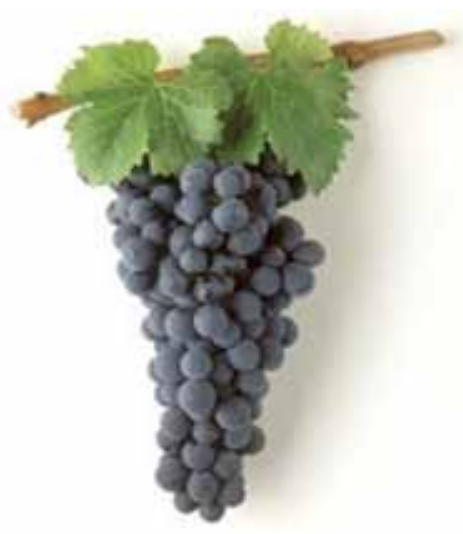

Među njima posebno se ističe sorta Tribidrag (Slika 2) za koju se u različitim područjima uzgoja koriste sinonimi kao: Crljenak kaštelanski, Pribidrag (Dalmacija), Primitivo (Italija), Zinfandel (SAD), Kratošija (Crna Gora) (Andabaka i sur., 2016). Revitalizirani Tribidrag je poradi stvarnih kvaliteta, ali i utjecaja medija u ekspanziji, ne samo u spomenutom vinogorju, nego i u ostalim vinogorjima u Dalmaciji.

Slika 2. Grozd Tribidraga

Figure 2. Tribidrag grape cluster

Izvor/Source:Tadić, 2016.

\section{Pregled ampelografskih zapažanja o kultivarima Babica i Tribidrag}

\section{Babica}

Procjenjuje se da je kroz zadnjih pedesetak godina Babica postala vodeća sorta na području vinogorja Kaštela-Trogir (Karoglan Kontić, 2006). Unatoč činjenici da u navedenom vinogorju predstavlja značajnu sirovinsku bazu za crna vina, i poznati opolo, tek od nedavno ju se navodi kao autohtonu sortu. Jedan od najvažnijih razloga tome, gotovo stoljetnom, nesporazumu leži u činjenici da je čitavo to vrijeme Babica smatrana Babićem (Vuletin, 1998), odnosno da je riječ o sinonimima. Ožanić (Anonymous, 1907, 1912, 1914) je spominje u svojim člancima, no ampelografski opisi nisu dostatni kako bi se sa sigurnošću moglo potvrditi da se radi upravo o Babici. Stipetić i Budimirović (1940) od kaštelanskog sortimenta spominju Crljenak, Ninčušu i Dobričić, ali ne i Babicu. Čak i Stjepan Bulić u svojemu kapitalnom djelu Dalmatinska ampelografija (1949), u kojemu je temeljito opisao 200 autohtonih dalmatinskih sorti, ne spominje Babicu kao autohtonu kaštelansku sortu već kao sinonim za Babić. Jedina Babica koja je navedena u toj knjizi je Babica plosnata crna s područja Zadra, dakle bez ikakve poveznice s Kaštelima. Tek Jelaska (1960) u kontekstu podizanja matičnjaka u Kaštel Lukšiću, uz crni Ljutun i bijele sorte Vlašku i Mladinku, spominje i Babicu, ali bez podrobnijih ampelografskih i inih karakteristika navedenih kultivara. Navodeći kako je udio crnih soti u vinogorju Kaštela-Trogir $85 \%$, a od njih najzastupljeniji Babić, ni Maleš (1987) ne rasvjetljava zabludu. Tek Zdunić (2005) daje potpunu ampelografsku obradu Babice, a konačnu potvrdu teze kako su Babić i Babica dvije različite sorte (Zdunić $i$ sur., 2008) potkrijepljene su spoznajama dobivenim najsuvremenijim molekularno-genetičkim metodama (Maletić i sur., 2008). Štoviše, utvrđeno je da je Babica direktan potomak Plavca malog (Slika 3). Prema podacima iz 2013. godine koje su objavili Maletić i sur. (2015) Babica je isključivo na području vinogorja Kaštela-Trogir zauzimala površinu od oko 18,5 ha. 


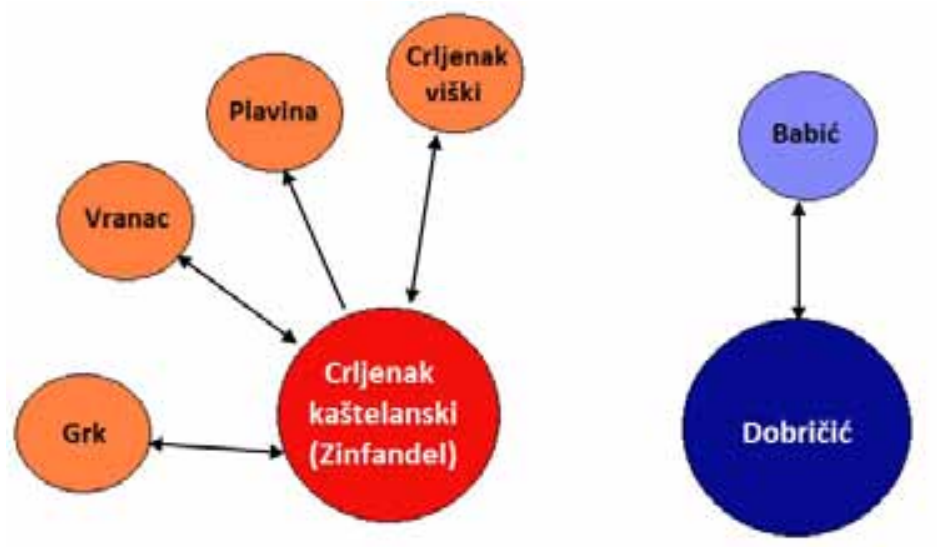

*Linije s jednom strelicom upućuju na odnos da je jedna sorta roditelj, a druga potomak, dok linije s dvije strelice upućuju da je veza moguća i u jednom i u drugom smjeru.

* Lines with one arrow pointing to the relationship that one grape variety is a parent and the other descendant, while lines with two arrows pointed that connection is possible in both sides.

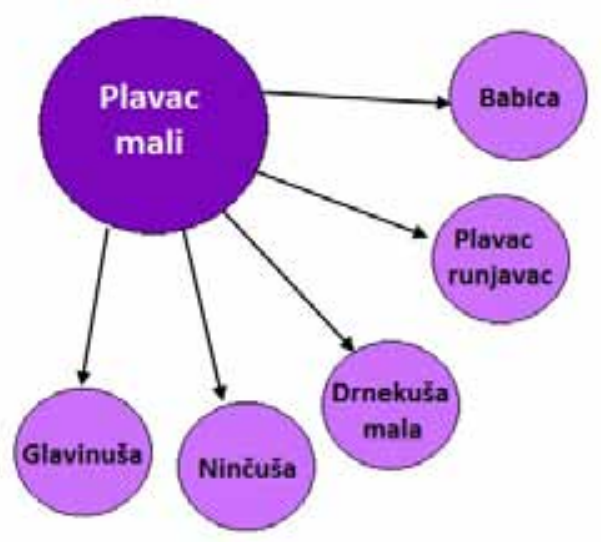

Slika 3. Pretpostavljeni odnosi različitih sorata s Crljenkom kašelanskim (Zinfandel) i Plavcem malim

Figure 3. Supposed relations of different cultivars with Crljenak kaštelanski and Plavac mali Izvor/Source: Maletić i sur., 2008.

\section{Tribidrag}

Razrješenje enigme o podrijetlu Zinfandela i revitalizacija Tribidraga mogli bismo s punim pravom karakterizirati kao najvažnije događaje u hrvatskom vinogradarstvu u proteklih četvrt stoljeća, pa i više od toga. U čitavoj šumi sinonima i homonima pod nazivom Crljenak na istočnoj obali Jadrana i u njenom zaleđu stotinama godina vinogradari su nazivali mnoge sorte tamne. u Dalmatinskoj ampelografiji ga spominje na mnogim lokacijama, no nigdje kao posebna sorta (Bulić, 1949).

Istovremeno, cijelo jedno stoljeće, traje interes vinogradarske javnosti u SAD-u, točnije u Kaliforniji, o podrijetlu njihove cijenjene sorte vinove loze i istoimenog vina Zinfandel (Piljac, 2005). Nakon što je dugo vremena fokus potrage bio usmjeren na talijansku pokrajinu Pugliu i njenu vinogradarsku uzdanicu Primitivo, pažnja istraživača je skrenuta na dalmatinsku obalu kao ishodišnu točku na kojoj se nalaze tragovi Zinfandela (Piljac, 2005). Da je Zinfandel ustvari Plavac mali tvrdili su Adams (1985) i Maleš (1993), no Wade Wolf je 
analizom izozima (izoenzima) dokazao razlike i time dokinuo njihovu pretpostavku (Piljac, 2005). Tek istraživanjima u kojima je primjenjena DNK analiza utvrđeno je da je nekoliko starih trsova pronađenih na obroncima planine Kozjak identično Zinfandelu, tj. da se radi o autohtonoj sorti Crljenak kaštelanski (Tribidrag) (Maletić i sur., 2004). U Šifrarniku vinskih sorata (NN 83/2014), pod šifrom CV280, Crljenak kaštelanski je upisan kao Tribidrag, što je prema sredstvima javnog priopćavanja, izazvalo revolt kod kaštelanskih vinara. Razlog je tome što je naziv Tribidrag kudikamo stariji, naime u staroj dalmatinskoj književnosti prisutan je još u 15. stoljeću (Tudor, 2010). U Budvanskom statutu iz 15. stoljeća spominje se i kao Kratošija (Luketić i Bujukić, 1988).

Osim u vinogorju Kaštela-Trogir ekspanzija Tribidraga događa se i na drugim vinogorjima podregije Srednje i Južne Dalmacije pa nasadi pod ovom sortom već dosežu površinu od 75 ha, a samo na područje Splitsko-dalmatinske županije otpada 28 ha (APPRRR, 2013).

\section{Karakteristike kultivara i vina Babice i Tribidraga}

Za pretpostaviti je da je Babica postala dominantna sorta u sortimentu vinogorja Kaštela- Trogir iz razloga što rađa redovito i obilno, a i poradi otpornosti prema bolestima (Tablica 1).

Ta kvalifikacija se može opravdati na primjeru berbe 2014, kada je uslijed učestalih kiša, prema iskustvu vinara s toga područja, bolest gotovo potpuno izostala, a nasadi Babice su ostali u dobrom zdravstvenom stanju.

Tablica 1. Usporedba bioloških i gospodarskih svojstava Babice i Tribidraga

Table 1. Comparison of biological and economic properties of Babica and Tribidrag

\begin{tabular}{|c|c|c|}
\hline & Babica & Tribidrag \\
\hline Fenološke karakteristike & $\begin{array}{l}\text { Vegetacija počinje srednje kasno. } \\
\text { Sorta dozrijeva u III. razdoblju. }\end{array}$ & $\begin{array}{l}\text { Vegetacija počinje srednje kasno. } \\
\text { Sorta dozrijeva rano do srednje } \\
\text { kasno (kraj II. razdoblja) }\end{array}$ \\
\hline Bujnost & Srednja. & Srednja. \\
\hline $\begin{array}{l}\text { Osjetljivost prema } \\
\text { biotskim i abiotskim } \\
\text { čimbenicima }\end{array}$ & $\begin{array}{c}\text { Nije osobito osjetljiva prema } \\
\text { plamenjači i pepelnici. } \\
\text { Zbog tanke kožice je osjetljivija na } \\
\text { sivu plijesan. }\end{array}$ & $\begin{array}{l}\text { Izraženo osjetljiv prema } \\
\text { gljivičnim bolestima, a naročito } \\
\text { sivoj plijesni. }\end{array}$ \\
\hline Rodnost i prinos & $\begin{array}{l}\text { Urod redovan. } \\
\text { Prinosi srednje visoki do visoki. }\end{array}$ & $\begin{array}{l}\text { Urod redovan. } \\
\text { Prinosi srednje visoki. }\end{array}$ \\
\hline Kakvoća & $\begin{array}{l}\text { Sadržaj šećera: srednje visok } \\
\text { Ukupna kiselost: niža do srednja } \\
\text { Boja kožice: plavo - crna } 6^{*}\end{array}$ & $\begin{array}{c}\text { Sadržaj šećera: visok } \\
\text { Ukupna kiselost: srednja } \\
\text { Boja kožice: plavo - crna 6* }\end{array}$ \\
\hline
\end{tabular}

"prema OIV deskriptorima (Zdunić, 2005)

"according to OIV descriptors (Zdunić, 2005)

Izvor/Source: Maletić i sur., 2015.

lako su, kako je u iz prikazanih podataka vidljivo (Tablica 2), u moštu niže vrijednosti šećera i kiselina u odnosu na Tribidrag, ova sorta na određenim položajima i uz primjerenu agrotehniku može ipak dati vina respektabilnog ranga, pa čak i više od toga (npr. vrhunsko vino Babica, proizvođač Kuzmanić). 
Tablica 2. Dostupni podaci o sadržaju šećera i ukupnoj kiselosti mošta za Babicu i Tribidrag u različitim godinama berbe

Table 2. Available data of sugar content and total acidity for Babica and Tribidrag from different vintages

\begin{tabular}{|c|c|c|c|c|}
\hline \multirow[b]{2}{*}{$\begin{array}{l}\text { Godina } \\
\text { berbe }\end{array}$} & \multicolumn{2}{|c|}{ Babica } & \multicolumn{2}{|c|}{ Tribidrag } \\
\hline & Šećer u moštu ('Oe) & $\begin{array}{c}\text { Ukupna kiselost } \\
\text { mošta } \\
\text { (g/l, izraženo kao } \\
\text { vinska) }\end{array}$ & $\begin{array}{l}\text { Šećer u moštu } \\
\left({ }^{\circ} \mathrm{Oe}\right)\end{array}$ & $\begin{array}{c}\text { Ukupna kiselost } \\
\text { mošta } \\
\text { (g/l, izraženo } \\
\text { kao vinska) }\end{array}$ \\
\hline 2002 & $77 a$ & $4,6 a$ & - & - \\
\hline 2003 & $84 \mathrm{a}$ & $2,5 \mathrm{a}$ & - & - \\
\hline 2006 & $83 \mathrm{~b}$ & $4,39 \mathrm{~b}$ & - & - \\
\hline 2007 & $94 \mathrm{~b}$ & $4,05 b$ & - & - \\
\hline 2008 & $95 \mathrm{~b}$ & $3,8 \mathrm{~b}$ & - & - \\
\hline 2009 & $85 \mathrm{~b}$ & - & - & - \\
\hline 2010 & - & - & $105 c$ & $5,1 \mathrm{c}$ \\
\hline 2011 & - & - & $107 c$ & $5,2 c$ \\
\hline 2012 & - & - & $101 \mathrm{c}$ & $5,8 \mathrm{c}$ \\
\hline 2013 & - & - & $100 / 98,5 c$ & $4,9 / 5,1 \mathrm{c}$ \\
\hline 2014 & - & - & $102 / 96 \mathrm{c}$ & $7,9 / 8,4 \mathrm{c}$ \\
\hline 2015 & - & - & $106 / 97,5 \mathrm{c}$ & $5,5 / 6,2 c$ \\
\hline
\end{tabular}

a- Podaci preuzeti iz Zdunić (2005)

a- data taken from Zdunić (2005)

$b$ - Podaci višegodišnjih mjerenja dobiveni iz kaštelanske zadruge "Kaštelacoop"

$b$ - data of multi-year measurements obtained from the Kaštela's cooperative "Kaštelacoop"

c- Podaci višegodišnjih mjerenja dobiveni od vinara iz Kaštel Štafilića

c- data of multi-year measurements obtained from winemaker from Kaštel Štafilić

Babica je niže alkoholična, nježnije boje i skromnijih fizikalno - kemijskih parametara (Tablica 3). S takvim je osobinama posebno prikladna za proizvodnju opola, koji se tradicionalno proizvodio, i još proizvodi, u Kaštelima (Bašić, 1999). 
Tablica 3. Fizikalno - kemijske karakteristike* vina Tribidrag i Babica, berba 2015

Table 3. Physico-chemical characteristics* of Tribidrag and Babica wines, vintage 2015

\begin{tabular}{|c|c|c|}
\hline Fizikalno-kemijske karakteristike* & Babica & Tribidrag \\
\hline Relativna gustoća $\left(20 / 20^{\circ} \mathrm{C}\right)$ & 0,9947 & 0,9996 \\
\hline Ukupni alkohol, (\% vol) & 12,5 & 14,2 \\
\hline Stvarni alkohol, (\% vol) & 12,5 & 14,0 \\
\hline Stvarni alkohol, (g/l) & 98,8 & 110,7 \\
\hline Ukupni ekstrakt suhi, (g/l) & 28,7 & 32,6 \\
\hline Reducirajući šećeri, (g/l) & 2,0 & 4,5 \\
\hline Ekstrakt bez reducirajućih šećera, (g/l) & 27,7 & 32,7 \\
\hline $\begin{array}{l}\text { Ekstrakt bez reducirajućih šećera i nehlapive } \\
\text { kiselosti, (g/l) }\end{array}$ & 24,4 & 28,0 \\
\hline Pepeo, (g/l) & 3,6 & 3,0 \\
\hline pH & 3,9 & 3,7 \\
\hline Ukupna kiselost, kao vinska (g/l) & 4,1 & 5,2 \\
\hline Hlapiva kiselost, kao octena (g/l) & 0,7 & 0,4 \\
\hline Nehlapiva kiselost, kao vinska (g/l) & 3,3 & 4,7 \\
\hline Slobodni sumporni dioksid (mg/l) & 25 & 9 \\
\hline Ukupni sumporni dioksid (mg/l) & 85 & 34 \\
\hline
\end{tabular}

*Analiza laboratorija Instituta za jadranske kulture i melioraciju krša

*Laboratory analyses of the Institute for the Adriatic Crops and Karst Reclamation

Tribidrag je u kratkom vremenu, otkako je doživio reafirmaciju, pokazao da posjeduje potencijal za izvrsna vina, najviše kvalitete, rezervirane u Dalmaciji isključivo za nekolicinu Plavaca malih, za primoštenski Babić. Dodatnoj reafirmaciji Tribidrag vina doprinijet će svakako i međunarodna konferencija nazvana "Ja sam Tribidrag" koja je održana u Splitu ove godine (27. i 28. travnja 2017.) (Anonymous, 2017).

Uvidom u biološka i gospodarska svojstva Tribidraga (Tablica 1) razvidni su razlozi njegova nestanka. Visoka osjetljivost na bolesti u doba skromnog izbora sredstava za zaštitu odvraćala je vinogradare od njegova uzgoja (Maletić i sur., 2015).

$U$ kišnoj 2014. godini Tribidrag se djelomično održao u na obroncima planine Kozjak, a onaj u polju je potpuno propao unatoč intenzivnoj primjeni fungicida (poglavito botricida). I u prošloj, 2016. „normalnoj” godini utvrđeno je propadanje grozdova Tribidraga uslijed pojave octene mušice (Drosophilla suzukii) i voćnog kusokrilca (Carpophilus hemipterus) popraćeno promjenom boje bobica i gubljenjem njihove čvrstoće, pri čemu im sadržaj postaje vodenast, a čitav vinograd miriše na ocat (Marušić i Bjeliš, 2017). 
Tribidrag redovito dostiže visoke šećere, a često i povišene kiseline (Tablica 2).

Po svome karakteru i organoleptičkim posebnostima ovo vino se ne da usporediti ni sa kojim drugim. lako visokih alkohola (Tablica 3), profinjene je arome i izbalansiranog tijela, mekanijih tanina i bržeg zrenja predstavlja sasvim nešto drugo u odnosu na Plavce čija je robusnost, divlji karakter (naročito u mladim vinima) i tvrdoća postala mjerilo i standard za dalmatinska crna vina (Callec, 1999).

Nije ni čudno da je Tribidrag stekao široki krug poklonika i postao pravi hit među ljubiteljima vina, a samim time povećala se i potražnja na tržištu, što je rezultiralo znatnim interesom za podizanjem novih nasada (Maletić $i$ sur., 2015).

\section{Zaključak}

Babica zaslužuje biti predmetom vinogradarskog interesa, tim više što sve mogućnosti njenog enološkog potencijala nisu iskorištene. Tu se u prvom redu misli na sadnju na položaje koji bi davali kvalitetniju sirovinu, primjenu aktualnih spoznaja o fenolnoj zrelosti, a u primarnoj preradi primjenu suvremenih postupaka. Ne treba zanemariti niti njen odnos prema biotskim i abiotskim čimbenicima što, u aktualnoj neizvjesnosti klimatskih promjena, a u svjetlu ekološke proizvodnje, predstavlja dragocjenu prednost. Babica sasvim sigurno ima svoje mjesto u niši autohtonih posebnosti, poglavito za onu vinarsku klijentelu koja, zasićena globalnim okusima, zahtijeva vina izraženijijh posebitosti.

U okolnostima recentne turističke ekspanzije, a vezano za to i komercijalnog uspjeha Tribidraga na tržištu, najgore što bi se moglo dogoditi jest širenje površina na račun napuštanja (krčenja i precjepljivanja) postojećih autohtonih kultivara vinogorja KaštelaTrogir. Pogrešno bi bilo opstanak neperspektivnih sorti prepustiti samo komercijalnoj logici, što bi po njih bilo kobno u smislu samog opstanka, kao i u održanju bioraznolikosti, održivosti i bogatstva genskog fonda.

\section{Literatura}

Adams, L.D. (1985) The Wines of America. New York: Mc Graw-Hill.

Andabaka Ž., Stupić D., Karoglan, M., Marković, Z., Preiner D., Maletić E., Karoglan Kontić, J. (2016) Povijesni tijek uzgoja najvažnijih autohtonih dalmatinskih sorata vinove loze (Vitis vinifera L.) Glasnik zaštite bilja, 3, 14-20.

Anonymous (1907) Gospodarski vjesnik, Zadar, broj 1. i 2.

Anonymous (1912) Gospodarski vjesnik, Zadar, broj 14

Anonymous (1914) Gospodarski list, Zadar, broj, 7. i 8.

Anonymous (2017) 1. međunarodna konferencija o vinskoj sorti Tribidrag, "Ja sam

Tribidrag", 27. i 28. travanj 2017. Split, Hrvatska; URL: https://tribidrag.org, (10.05.2017).

APPRRR-Agencija za placanja u poljoprivredi, ribarstvu i ruralnom razvoju (2013) Stanje

površina u Arkod sustavu i Vinogradarskom registru.

Bulić, S. (1949) Dalmatinska ampelografija. Zagreb: Poljoprivredni nakladni zavod.

Jelaska, M. (1960) Ampelografija dalmatinskih sorata. Split: Institut za mediteransku poljoprivredu

i melioraciju krša, Split.

Bašić, Ž. (1999) Vina Dalmacije. Split: Zadružni savez Dalmacije.

Callec, C. (1999) Wine encyclopaedia, Lisse: Rebo International B.V.

Karoglan Kontić, J. (2006) Model revitalizacije autohtonih sorata vinove loze. Završno

izvješće. Zagreb: Agronomski fakultet Sveučilišta u Zagrebu. URL: www.savjetodavna.hr/adminmax/researches/ Završno_izvjesce_Karoglan_Kontic.doc (15.03.2017)

Luketić, M., Bujukić, Ž. (1988) Srednjovjekovni statut Budve. Budva: Istorijski arhiv.

Maleš, P. (1987) Vinogradarstvo i vina Dalmacije. Split: Institut za jadranske kulture i melioraciju krša Split.

Maleš, P. (1993) Populacija: (plavac mali-zinfandel-primitivo). Rijeka: Vitagraf.

Maletić, E., Pejić I., Karoglan, Kontić, J., Piljac J., Dangl., G.S., Vorkuta A., Lacombe T.,

Mirošević, N., Meredith, C.P. (2004) Zinfandel, Dobričić and Plavac mali: The Genetic

Relationship among Three Cultivars of the Dalmatian Coast of Croatia. American Journal of

Enolology and Viticulture 55(2), 79-83.

Maletić, E., Kontić, K., J., Pejić, I. (2008) Vinova loza. Zagreb: Školska knjiga.

Maletić, E., Kontić Karoglan, J., Prenier, D., Zdunić,G., Bubola, M., Stupić, D., Andabaka,

Ž., Marković, Ž., Šimon, Š., Mihaljević, Žulj, M., Ilijaš, I., Marković, D. (2015) Zelena 
knjiga: Hrvatske izvorne sorte vinove loze. Zagreb: Državni zavod za zaštitu prirode.

Marušić, S., Bjeliš, M. (2017) Pojava novih štetnika. U: Cvjetković, B, ur. Glasilo biljne zaštite 1/2. Dodatak, Zbornik sažetaka. 61. Seminara biljne zaštite, Opatija od 7. do 10. veljače 2017. Zagreb: Hrvatsko društvo biljne zaštite, Sveučilište u Zagrebu, Agronomski fakultet, 18.

Piljac, J. (2005) Zinfandel, Čakovec: Zrinski d.d.

Pravilnik o registru vinograda, obveznim izjavama, pratećim dokumentima, podrumskoj evidenciji i proizvodnom potencijalu.(2014), Zagreb: Narodne novine 48.

Pravilnik o izmjenama Pravilnika o registru vinograda, obveznim izjavama, pratećim dokumentima, podrumskoj evidenciji i proizvodnom potencijalu. (2014), Zagreb: Narodne novine 83.

Stipetić M., Budimirović S., (1940) Vina Banovine Hrvatske. Zagreb: Izdanje Odjela za seljačko gospodarstvo Banske vlasti Banovine Hrvatske.

Tadić, A. (2016) Tribidrag - obilježje sorte i vina. Colloqvinum, wine magazine.

URL: http://magazine.colloqvinum.com/tribidrag-obiljezje-sorte-vina/ (10.05.2017.)

Tudor, A. (2010) Nekoliko povijesnih podataka o Tribidragu (Zinfandel, Crljenak

kaštelanski, Tribidrag). Mogućnosti: književnost, umjetnost, kulturni problemi. 1 (7-9), 103-109.

Vuletin, B. (1998) Vinogradarstvo i vinarstvo Kaštela. Zbornik radova sa simpozija: "Kaštela

kolijevka Hrvatske", Kaštel Stari od 30. rujna do 3. listopada 1998. godine, pp 589-593.

Zdunić, G. (2005) Ampelografska i genetička evaluacija autohtonih sorata vinove loze (Vitis

vinifera L.) u području Kaštela. Magistarski rad. Zagreb: Agronomski fakultet Sveučilišta u Zagrebu.

Zdunić, G., Pejić, I., Karoglan Kontić, J., Vukičević, D., Vokurka, A., Pezo, I., Maletić, E. (2008) Comparison of genetic and morphological data for inferring similarity among native Dalmatian (Croatia) grapevine cultivars (Vitis vinifera L.). Journal of Food, Agriculture \& Environment 6 (2), 333-336.

\title{
Comparison of the characteristics of grape varieties Babica and Tribidrag
}

\begin{abstract}
In the vineyard area of Kaštela - Trogir many autochthonous grapevine cultivars are cultivated. Among red wine cultivars Babica cultivar has been mostly represented. After DNA analysis proved that Tribidrag is genetically identical with Californian Zinfandel and Italian Primitivo cultivars, its revitalisation has begun. Because of commercial reasons Tribidrag grape growing areas have been increasing while those cultivating Babica and other grape varieties have been gradually decreasing. It has been observed that recently some new difficulties in cultivation of Tribidrag cultivar have appeared, whereas Babica deserves to become the focus of vine growing interest as all the possibilities of its enological potential are not fully exploited. Keywords: Babica, Tribidrag, vineyard area of Kaštela-Trogir, historical data, comparison.
\end{abstract}

